\title{
Characterizing affinity epitopes between prion protein and $\beta$-amyloid using an epitope mapping immunoassay
}

\author{
Mino Kang ${ }^{1}$, Su Yeon $\mathrm{Kim}^{2}$, Seong Soo $\mathrm{A} \mathrm{An}^{1}$ and Young Ran $\mathrm{Ju}^{2}$ \\ Cellular prion protein, a membrane protein, is expressed in all mammals. Prion protein is also found in human blood as an \\ anchorless protein, and this protein form is one of the many potential sources of misfolded prion protein replication during \\ transmission. Many studies have suggested that $\beta$-amyloid 1-42 $_{1}$ oligomer causes neurotoxicity associated with Alzheimer's \\ disease, which is mediated by the prion protein that acts as a receptor and regulates the hippocampal potentiation. The \\ prevention of the binding of these proteins has been proposed as a possible preventative treatment for Alzheimer's disease; \\ therefore, a greater understanding of the binding hot-spots between the two molecules is necessary. In this study, the epitope \\ mapping immunoassay was employed to characterize binding epitopes within the prion protein and complementary epitopes in \\ $\beta$-amyloid. Residues 23-39 and 93-119 in the prion protein were involved in binding to $\beta$-amyloid ${ }_{1-40}$ and ${ }_{1-42}$, and monomers \\ of this protein interacted with prion protein residues 93-113 and 123-166. Furthermore, $\beta$-amyloid antibodies against the \\ C-terminus detected bound $\beta$-amyloid - $_{1-42}$ at residues 23-40, 104-122 and 159-175. $\beta$-Amyloid epitopes necessary for the \\ interaction with prion protein were not determined. In conclusion, charged clusters and hydrophobic regions of the prion protein \\ were involved in binding to $\beta$-amyloid ${ }_{1-40}$ and $1-42$. The 3D structure appears to be necessary for $\beta$-amyloid to interact with \\ prion protein. In the future, these binding sites may be utilized for 3D structure modeling, as well as for the pharmaceutical \\ intervention of Alzheimer's disease.
}

Experimental \& Molecular Medicine (2013) 45, e34; doi:10.1038/emm.2013.63; published online 2 August 2013

Keywords: Alzheimer's disease; amyloid- $\beta$; epitope mapping; ligand; prion protein

\section{INTRODUCTION}

The cellular prion protein (PrPC) is a membrane protein with a glycophosphatidylinositol anchor that is expressed in all mammals. PrPC is also found in blood as an anchorless protein. ${ }^{1}$ The accumulation of the toxic misfolded infectious form of the prion protein in the brain is a well-known characteristic of transmissible spongiform encephalopathies, which are better known as prion diseases. ${ }^{2}$ Although the PrPC to misfolded prion protein conversion mechanism has not been clearly determined, conformational changes in the protein structure that transform $\alpha$-helices to $\beta$-sheets were observed using circular dichroism analysis. ${ }^{3}$

Several functions of PrPC were suggested in the absence of clear knowledge of the role of PrPC, and PrPC knockout mice did not display any noticeable defects during their growth and development. ${ }^{4,5}$ Interestingly, a previous study of the ${ }^{23} \mathrm{KKRPKPGGW}^{31}$ region in the PrPC peptide suggested that this region contains a neuroprotective functional moiety. ${ }^{6}$
Other protective roles of PrPC were suggested by other groups in experiments involving Bax overexpression, ${ }^{7,8}$ oxidative stress $^{9,10}$ and mitochondrial dysfunction induced by serum deprivation. ${ }^{11}$ Furthermore, amino acids $106-126$ of PrPC comprise a short toxic peptide sequence that mimics misfolded prion protein aggregation. ${ }^{12}$ Overall, PrPC may be involved in the neuroprotective and neurotoxic functions, but the effects remain unclear. ${ }^{13}$

Similar to the misfolded prion protein pathogenic protein, $\beta$-amyloid $_{1-42}(A \beta 42)$ has been shown to be involved in Alzheimer's disease $(\mathrm{AD})$. AD is a neurodegenerative disorder that accompanies memory loss and impaired cognitive function. Clinically, the accumulation of $A \beta$ in senile plaques and the hyperphosphorylation of Tau protein in neurofibrillary tangles in the brain are representative hallmarks of $\mathrm{AD}$ patients. ${ }^{14-16}$ During $\mathrm{AD}$ pathogenesis, $\mathrm{A} \beta$ accumulation is considered to be the first mechanism of progression, which is based on observed cognitive impairments followed by

\footnotetext{
${ }^{1}$ Department of Bionanotechnology, Gachon University, Gyeonggi, Korea and ${ }^{2}$ Division of Zoonoses, Center for Immunology and Pathology, National Institute of Health, Korea Centers for Disease Control and Prevention, Osong, Republic of Korea

Correspondence: Professor SSA An, Department of Bionanotechnology, Gachon University, 65 San, Bokjeong-dong, Sujeong-gu, Seongnam-si, Gyeonggi-do 461-701, South Korea. 
intraneuronal $A \beta$ accumulation. ${ }^{17}$ Therefore, $A \beta$ aggregation is considered to be the most pathogenic process in AD. ${ }^{18-23}$

The production of $\mathrm{A} \beta 42$ results from $\beta$ - and $\gamma$-secretasemediated cleavage of the amyloid precursor protein. ${ }^{24}$ This 42 amino-acid peptide spontaneously aggregates, which creates toxic plaques in the brain. ${ }^{25}$ However, the mechanisms of the amyloid cascade remain unclear due to the lack of correlation between the number of plaques and cognitive decline. ${ }^{26,27}$ Among heterogeneous conformations of $\mathrm{A} \beta 42$ (monomers, oligomers and fibrils), oligomeric $A \beta 42$ has been suggested to be the primary cause of AD. ${ }^{28-32}$ Soluble A $\beta 42$ oligomers have been strongly correlated with synaptic loss, as well as the accumulation of intracellular $\mathrm{A} \beta$ in $\mathrm{AD}$ pathophysiology. ${ }^{33}$

The toxic mechanisms mediated by $A \beta$ oligomers during $\mathrm{AD}$ pathogenesis have still not been elucidated. Various $\mathrm{A} \beta$ oligomer structures that form in the extracellular matrix may induce apoptotic cell death and oxidative stresses by interacting with various receptors such as the pan-specific p75 neurotrophin receptor, ${ }^{34}$ the $N$-Methyl-D-aspartate-type glutamate receptor, ${ }^{35}$ the Frizzled receptor ${ }^{36}$ and the insulin receptor. $^{37}$ However, membrane-bound PrPC, which is a receptor for $A \beta$ oligomers, was suggested to be involved in regulating long-term potentiations in the hippocampus that were induced by oligomeric $\mathrm{A} \beta 42 .{ }^{38}$ Furthermore, the binding of A $\beta 42$ oligomers to PrPC was inhibited when 6D11, an antiPrPC antibody against the epitope containing amino acids 93-109, was used to treat the cells expressing PrPC. ${ }^{39}$ These studies indicate the potential role of $\mathrm{PrPC}$ as a receptor that mediates the toxic effects of A $\beta 42$ oligomers. In contrast, other studies have suggested that PrPC-mediated A $\beta 42$ oligomer toxicity may not be the only mechanism that causes its toxicity. ${ }^{40,41}$

In previous studies, the binding sites in PrPC that mediate the interaction with $\mathrm{A} \beta 42$ were analyzed using competitive antibody assays ${ }^{39}$ and surface plasmon resonance. ${ }^{40}$ Nuclear magnetic resonance (NMR) and the simulation of a PrPC and A $\beta 42$ docking model suggested that both $A \beta 42$ monomers and dimers bind to a similar site in PrPC. ${ }^{42}$ Antibody or proteinprotein interaction epitope mapping using multiple overlapping peptides has been widely applied, and a large amount of research data has been accumulated. Therefore, resources such as SPOTs synthesis ${ }^{43}$ (Sigma's custom SPOTs service) and other similar methods (for example, the pin-bound peptides method $^{44}$ and free peptide assays ${ }^{45}$ ) are already available.

In the present study, the PrPC epitopes involved in $\mathrm{A} \beta 42$ binding were investigated using epitope mapping immunoassays. The principles of this method and its applications are introduced throughout this paper. We determined that PrPC binds to $A \beta 40$ in addition to $A \beta 42$, which was previously reported. Through experimentation, we determined that the $3 \mathrm{D}$ structure of $\mathrm{A} \beta 42$ appeared to be important for the binding to PrPC. The investigation of $\mathrm{PrP}$ and $\mathrm{A} \beta$ interaction sites provides a greater understanding of the actions of PrPC as a receptor and assists in the development of immunoassay diagnostic tools and the creation of pharmaceutical interventions for $\mathrm{AD}$.

\section{MATERIALS AND METHODS}

All overlapping peptides were synthesized using Fmoc solid-phase peptide synthesis from Anygen (Jeollanam-do, South Korea), with approximately $90 \%$ purity. His-tagged PrPC (human) was purified from Escherichia coli using Ni-NTA agarose beads, ${ }^{46}$ and $\mathrm{A} \beta 40$ and A $\beta 42$ were purchased from Bachem (Bubendorf, Switzerland). SAF-32 antibody purchased from Cayman Chemical (Ann Arbor, MI, USA) and 6D11, 1E11, 6E10 and 4G8 antibodies obtained from Signet Laboratories (Dedham, MA, USA) were used to test the efficacy of the epitope mapping enzyme-linked immunosorbent assay (EpiMap ELISA) tests, depending on their respective antigens. Horseradish peroxidase (HRP)-conjugated anti-PrPC antibody was kindly provided by $\mathrm{Dr} \mathrm{T}$. Yokoyama, ${ }^{47}$ and biotin-conjugated $\mathrm{A} \beta 42$ antibody against the C-terminus (6D5) was purchased from US Biological (Swampscott, MA, USA). Maleimide-activated microplates were used to conjugate the overlapping peptides to cysteine residues. HRP-conjugated NeutrAvidin and salmon serum albumin (SeaBlock) were purchased from Thermo Scientific (Rockford, IL, USA). Additionally, 96-well black MaxiSorp plates were purchased from Nunc (\#475515, Roskilde, Denmark). Phosphate-buffered saline (PBS), PBS with $0.05 \%$ Tween 20 (PBST), Tris-buffered saline with $0.05 \%$ Tween 20 (TBST), ethylenediaminetetraacetic acid, HRPconjugated goat anti-mouse IgG, dimethyl sulfoxide (DMSO) and $3,3^{\prime}, 5,5^{\prime}$-tetramethylbenzidine were purchased from SigmaAldrich (St Louis, MO, USA). Dynabeads M-280 Tosylactivated magnetic beads were purchased from Invitrogen (Oslo, Norway). BLOCK ACE (AbD Serotec, Raleigh, NC, USA) was dissolved in distilled water to make a $4 \%$ solution.

The preparation of the PrPC and A $\beta 42$ EpiMap ELISA tests Both human PrPC and A $\beta 42$ sequences were obtained from the universal protein resource knowledgebase (UniProtKB). Forty-four overlapping 17-mer peptides were synthesized by shifting three amino acids from the $\mathrm{N}$ - to C-terminus of the PrPC sequence, where each peptide was numbered consecutively. These peptides were generated with a cysteine at the end of the $\mathrm{N}$ - or C-terminus of each peptide, except for the peptides numbered 29, 30, 31, 32, $33,41,42,43$ and 44 because their inner cysteine residue was used. The peptides numbered 10,12, 13, 18 and 39 failed to be synthesized due to aggregation problems, and partial sequences of the octapeptide repeat region were omitted (Figure 1a).

The human $A \beta 42$ sequence from UniProt was used to design 15 -mer peptides from the $\mathrm{N}$ - to $\mathrm{C}$-terminus of $\mathrm{A} \beta 42$. A cysteine residue was designed at the $\mathrm{C}$-terminus of the peptides numbered 1-8 and the N-terminus of the peptides 9-16 (Figure 1b). Unfortunately, peptide 15 could not be synthesized due to an aggregation problem. The cysteine residue provided a sulfhydryl group to link the peptides on the plate through a maleimide reaction. A schematic description of the EpiMap ELISA preparation is presented in Figure 2.

This protocol was designed on the basis of the manufacturer's instructions. All peptides were solubilized in DMSO at high concentrations and were then further diluted in PBS ( $\mathrm{pH} 4.5)$ to prevent dimerization. Peptides were reconstituted to $5 \mu \mathrm{g} \mathrm{ml}^{-1}$ in PBS ( $\mathrm{pH}$ 7.2) containing $10 \mathrm{~mm}$ ethylenediaminetetraacetic acid and were immediately added to the maleimide-activated 96-well plates $(100 \mu \mathrm{l}$ per well). Next, the peptides were incubated overnight at $4{ }^{\circ} \mathrm{C}$ and blocked using $10 \mu \mathrm{g} \mathrm{ml}^{-1}$ of cysteine $(200 \mu \mathrm{l}$ per well $)$ for the remaining maleimide groups. The plates were then washed three times with $300 \mu$ l of PBST (pH 7.4). 

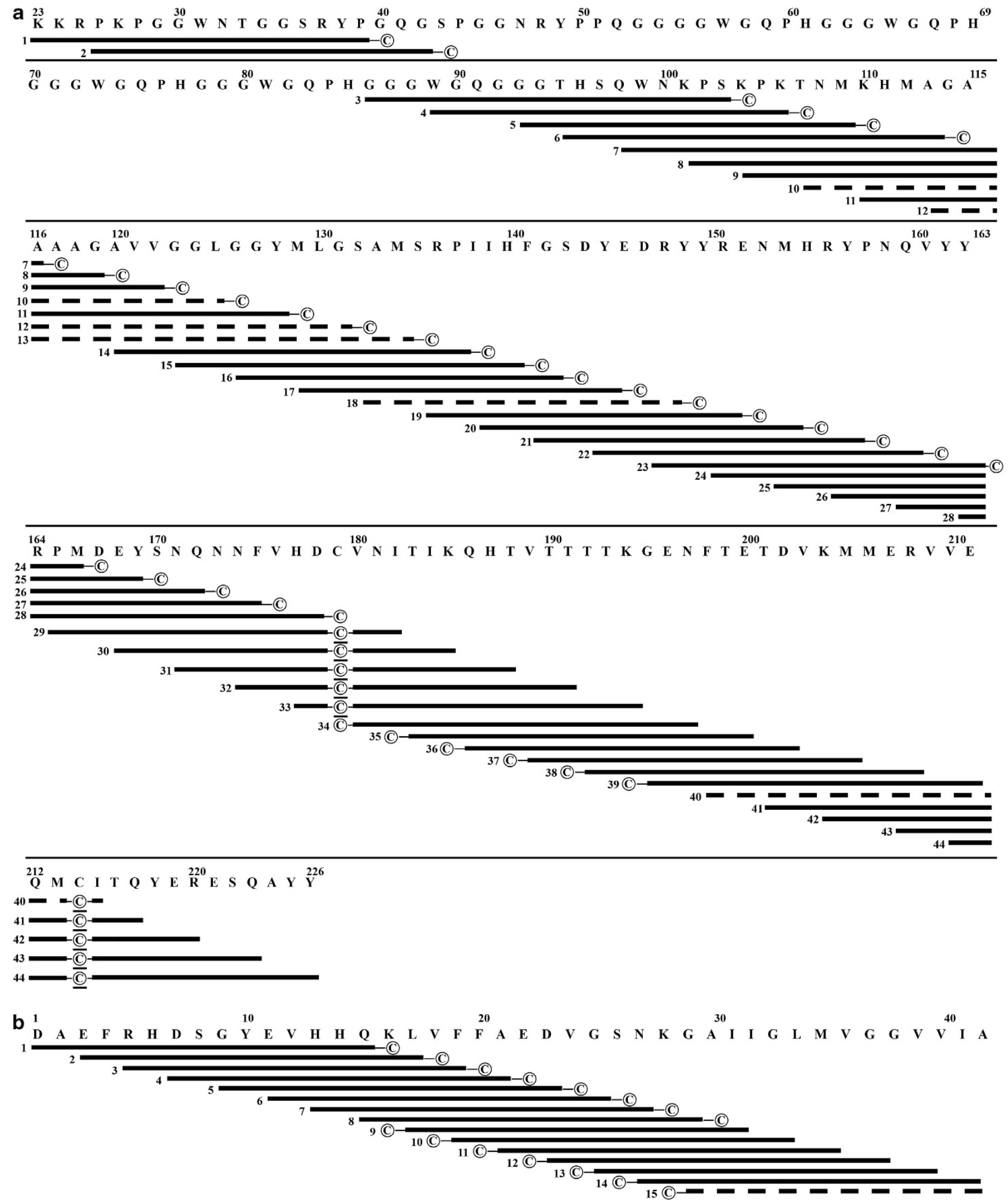

Figure 1 Schematic figures of (a) cellular prion protein and (b) $\beta$-amyloid - $_{1-42}$ overlapping peptides. Each black bar represents overlapping peptides and their locations, while -(c) indicates the cysteine residue used for peptide conjugation.

The evaluation of the PrPC and Aß42 EpiMap ELISA tests The PrPC monoclonal antibodies with known epitopes such as SAF-32 (epitopes, 57-88), 6D11 (epitopes, 91-109), A 342 antibodies (1E11 (epitopes, 1-8) and HRP-conjugated 4G8 (epitopes, 17-25)) were used to assess the epitope mapping potential of the EpiMap ELISA. Antibodies were reconstituted to $0.01 \mu \mathrm{g} \mathrm{ml}^{-1}$ in TBST $(\mathrm{pH}$ 8.0) with $0.4 \%$ BLOCK ACE. After a 1 -h incubation period, each well was washed three times in $300 \mu$ of TBST. The HRP-conjugated 


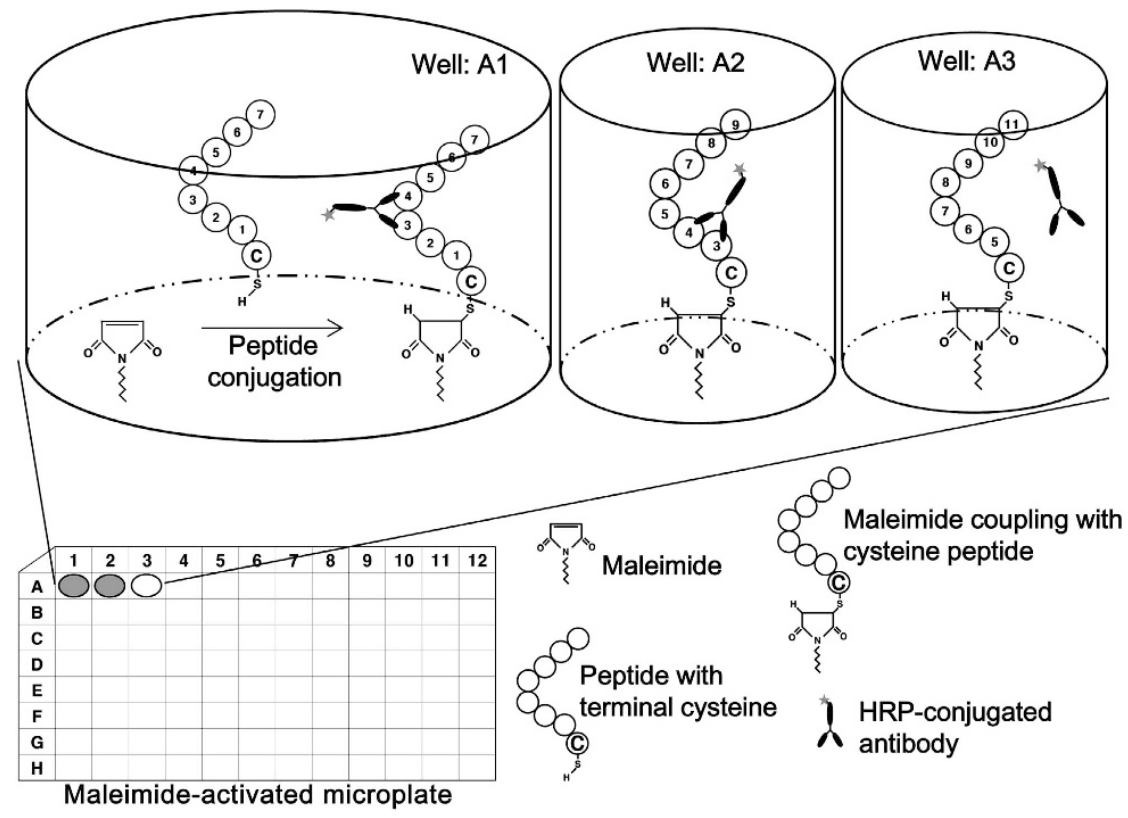

Figure 2 The principles of overlapping peptide conjugation and epitope mapping strategies. A sulfhydryl group from a cysteine at the end of each overlapping peptide was conjugated through a maleimide reaction onto a maleimide-activated plate. If the antibody targeted amino acids 3 and 4 of the peptide, the antibody detected overlapping peptides that contained the same epitopes. The overlapping peptide in Well:A3 did not contain amino acids 3 and 4; therefore, the antibody did not bind to the overlapping peptide. Therefore, no enzymatic chemical changes occurred in Well:A3 (presented as blanked circle). Increased absorbances were observed in Well:A1 and Well:A2 (presented as gray circles), which was then calculated to identify significant binding epitopes. In addition to antibody epitope mapping, protein-protein interaction sites were identified using the same principle.

anti-mouse IgG antibody (1:5000) was added, and the mixture was incubated for $1 \mathrm{~h}$ at $37^{\circ} \mathrm{C}$ followed by three washes in TBST. An HRP signal was visualized by determining the absorbance at $450 \mathrm{~nm}$ after sequential additions of $3,3^{\prime}, 5,5^{\prime}$-tetramethylbenzidine (100 $\mu$ l per well) and sulfuric acid $(50 \mu \mathrm{l}, 2 \mathrm{~N})$

\section{$\beta$-amyloid preparation and electrophoresis}

$A \beta 40$ and $A \beta 42$ in lyophilized form were dissolved in DMSO. A $\beta$ in DMSO was further diluted in PBS to a final amount of $5 \mu \mathrm{g}$ and incubated for $2 \mathrm{~h}$ at $37^{\circ} \mathrm{C}$ before electrophoresis. Mini-PROTEAN Tris-Tricine precast gels (10-20\%) from Bio-Rad Laboratories (Hercules, CA, USA) were prepared with $1 \mathrm{X}$ cathode buffer $(0.1 \mathrm{~mm}$ Tris, $0.1 \mathrm{~mm}$ Tricine, $0.1 \%$ SDS and $\mathrm{pH} 8.3$ ) in the top chamber of the gel and $1 \mathrm{X}$ anode buffer $(0.2 \mathrm{M}$ Tris, $\mathrm{pH} 8.9)$ in the bottom chamber. The proteins were separated in an iced chamber at $150 \mathrm{~V}$, and silver staining was performed (Pierce \# 24612, Rockford, IL, USA).

\section{Protein epitope mapping with EpiMap ELISA}

Overall, 42-amino-acid sequences in PrPC were predicted to be involved in the interaction with $A \beta 40$ by applying $0.1 \mu \mathrm{g} \mathrm{ml}^{-1}$ of A $\beta 420$ and by using the PrPC EpiMap ELISA plate ( $100 \mu \mathrm{l}$ per well). After $1 \mathrm{~h}$ at $37^{\circ} \mathrm{C}$, each well was washed three times with $300 \mu \mathrm{l}$ of PBST, and anti-A $\beta 42$ (6E10) HRP-conjugated antibodies were applied at $0.1 \mu \mathrm{g} \mathrm{ml}^{-1}$ in PBST with $0.4 \%$ BLOCK ACE. For the 6D5 biotinylated antibody, $0.1 \mu \mathrm{g} \mathrm{ml}^{-1}$ was applied under the same conditions, and NeutrAvidin-HRP (1:5000) was added after three consecutive washes. In another A $\beta 42$ EpiMap ELISA experiment, PrPC reconstituted with PBST $\left(0.1 \mu \mathrm{g} \mathrm{ml}^{-1}, 100 \mu \mathrm{l}\right.$ per well) was applied to A $\beta 42$ EpiMap ELISA plate and incubated for $1 \mathrm{~h}$ at $37^{\circ} \mathrm{C}$. After three washes with $300 \mu$ of PBST, the anti-PrP antibodies (T2 or
SAF-32) were applied at $0.1 \mu \mathrm{g} \mathrm{ml}^{-1}$ in PBST with $0.4 \%$ BLOCK ACE. After $1 \mathrm{~h}$ of incubation, the microplates were washed three times with PBST. Subsequently, 3,3',5,5'-tetramethylbenzidine ( $100 \mu \mathrm{l}$ per well) was applied to both EpiMap ELISA plates and was incubated for 20 min. Finally, the reaction was quenched with $\mathrm{H}_{2} \mathrm{SO}_{4}(50 \mu \mathrm{l}, 2 \mathrm{~N})$.

\section{The recombinant PrPC and A 342 interaction}

The recombinant $\mathrm{PrPC}$ and $\mathrm{A} \beta 42$ proteins were conjugated to Tosylactivated magnetic beads following the manufacturer's protocol (Invitrogen, Oslo, Norway). Briefly, $1 \mu \mathrm{M}$ of each protein in phosphate buffer $(0.1 \mathrm{M})$ was incubated with magnetic beads $\left(4 \times 10^{8}\right.$ beads $)$ for $24 \mathrm{~h}$ at $37^{\circ} \mathrm{C}$. Non-specific binding was reduced by incubating in $1 \%$ BLOCK ACE for $4 \mathrm{~h}$. Approximately, $4 \times 10^{6}$ beads in $50 \mu \mathrm{l}$ were used for each sample, and $100 \mu \mathrm{l}$ of PrPC $\left(10 \mathrm{ng} \mathrm{ml}^{-1}\right)$ was used for the binding experiments. The final volume of the assay was fixed to $200 \mu \mathrm{l}$ by adding TBST ( $\mathrm{pH}$ 8.0). In the assay, PrPC was added to A $\beta 42-$ and BA-conjugated magnetic beads where HRP-conjugated anti-PrPC $\left(0.1 \mu \mathrm{g} \mathrm{ml}^{-1}\right)$ detected any bound PrPC. For negative controls, A $\beta 42$ - and BA-conjugated magnetic beads were incubated with PrPC antibody, while PrPC-conjugated magnetic beads were used as a positive control. Enhanced chemiluminescence HRP substrate $(200 \mu \mathrm{l})$ was added, and the luminescence signals were measured with a Victor $^{3}$ multi-spectrophotometer (Perkin Elmer, Boston, MA, USA) in relative luminescence units (RLU).

\section{Statistical analysis}

All assays were performed in triplicate, and quantitative data were compared among the groups using Student's $t$-test in MiniTab version 14 (Minitab Inc., State College, PA, USA). The differences were considered to be significant at $P \leq 0.05$. Data analysis for epitope 
mapping adapted guidelines from a previous review paper. ${ }^{48}$ First, the average absorbance detected from each overlapping peptide was determined and was subtracted by the lowest quartile (25\%) to provide the corrected data. Second, the corrected data were divided by the mean of average absorbance from all peptides to generate normalized data (in $\sigma$ units). These normalized data were assigned to each overlapping peptide; therefore, each amino acid in the overlapping peptides was allocated with the same normalized data obtained from the overlapping peptides. At last, these normalized data were assigned to the amino acids that belong to the overlapping peptide. The amino acids from the first overlapping peptide overlap with one another; therefore, the normalized data that indicated the same amino acids were summed to provide the 'sum of normalized activity'. The data above $5 \sigma$ units were considered to be positive with a good degree of confidence based on the previous review paper. ${ }^{48}$

\section{RESULTS}

The preparation of PrPC and Aß42 EpiMap ELISA tests

The EpiMap ELISA was prepared from an array of synthetic peptides on 96-well microtiter plates using 44 overlapping peptides $(17$ mer) from the $\mathrm{N}$ - to C-terminus of the PrPC sequence (Figure 1a). Using the A $\beta 42$ EpiMap ELISA, 15 overlapping peptides $(15 \mathrm{mer})$ from the $\mathrm{N}$ - to C-terminus of A $\beta 42$ (Figure 1b) were synthesized and immobilized onto 96-well plates. Overlapping peptides were synthesized with a cysteine residue at the $\mathrm{N}$ - or C-terminal ends to conjugate on the maleimide-activated microplates through their free sulfhydryl group. Increased hydrophobicity of overlapping peptides was anticipated with the addition of a cysteine. Unfortunately, the PrPC peptides no. 10, 12, 13, 18 and 40
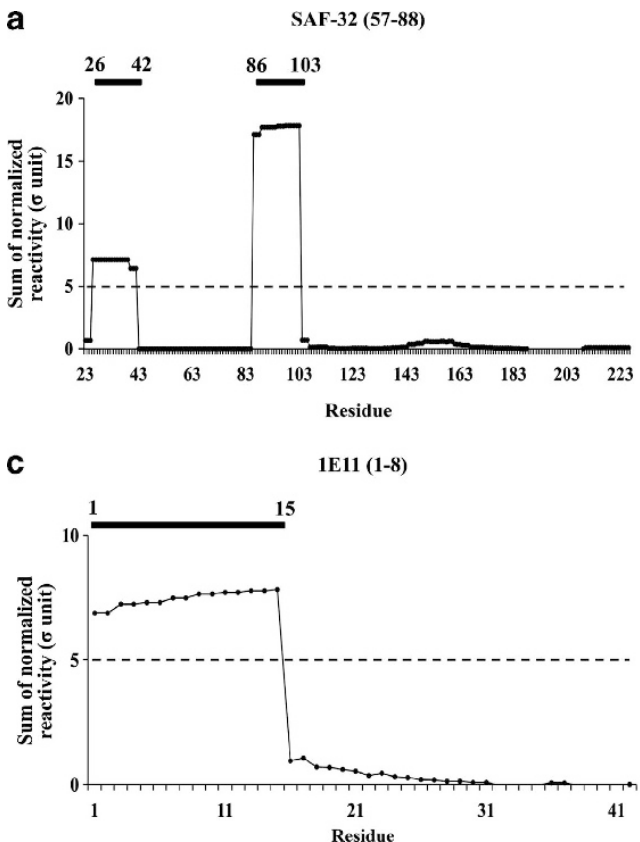

could not be purified because they formed aggregates upon release from the solid-phase peptide synthesis beads. Regarding the $A \beta 42$ overlapping peptides, peptide no. 15 was also lost due to aggregation. The overlapping peptides were conjugated to a maleimide-activated microplate through a cysteine residue. A schematic explanation of the overlapping peptide conjugation as well as the basic principle of the EpiMap ELISA test is explained in Figure 2.

\section{The evaluation of PrPC and Aß42 EpiMap ELISA tests}

Well-characterized commercial PrPC antibodies with the known epitopes, SAF-32 and 6D11, were applied to the PrPC EpiMap ELISA for validation. The SAF-32 epitope (residues 59-89) or the octapeptide repeat region of $\operatorname{PrPC}^{49}$ were analyzed by the PrPC EpiMap ELISA and showed significant binding ( $>5 \sigma$ units) in regions 26-42 and 86-103 (Figure 3a). The end of the octapeptide repeat region was detected with SAF-32; however, the repeat region was omitted in the PrPC EpiMap ELISA. Another PrPC antibody, 6D11 (epitope $\left.93-109^{50}\right)$, was tested using the same procedure. Absorbance was measured at $450 \mathrm{~nm}$ and was calculated as the sum of normalized data to identify the binding epitope. The PrPC residues $89-116$ were found to have significant binding ( $>5 \sigma$ units) (Figure 3b).

A microplate that conjugated with $A \beta 42$ overlapping fragments (A $\beta 42$ EpiMap ELISA) was validated with A $\beta 42$-specific antibodies, 1E11 (residues 1-8; Covance) and 4G8 (residues 17-24; Covance). Based on the A $\beta 42$ EpiMap ELISA, 1E11 and $4 \mathrm{G} 8$ were found to be significantly reactive ( $>5 \sigma$ units)
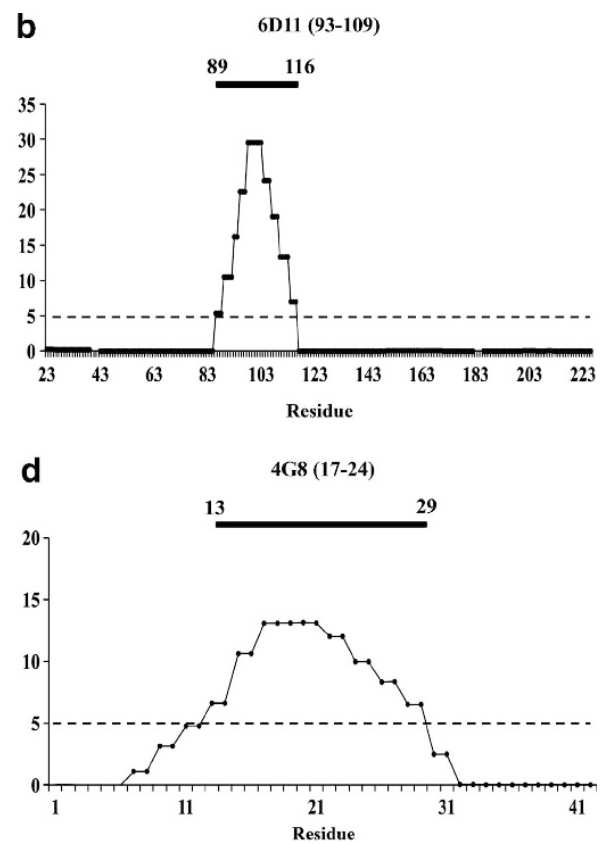

Figure 3 Epitope-known cellular prion protein (PrPC) antibodies: (a) SAF-32 antibody and (b) 6D11, and $\beta$-amyloid $1-42$ (Aß42) antibodies (c) $1 \mathrm{E} 11$ and (d) $4 \mathrm{G} 8$ were tested in PrPC or A 42 epitope mapping enzyme-linked immunosorbent assay (EpiMap ELISA) experiments. The known epitopes of the antibodies are indicated adjacent to the name of the antibody in brackets. The $\mathbf{X}$ axis of $\mathbf{a}$ and $\mathbf{b}$ shows the PrPC amino acid number, while $\mathbf{c}$ and $\mathbf{d}$ are the A 342 amino acid number. The sum of normalized reactivity, which is calculated based on the absorbance of each overlapping peptide, is represented as the $Y$ axis. The black bar and number indicate the binding epitopes of the antibodies that were used in the EpiMap ELISA experiment. 
to residues 1-15 and 13-29 of A $\beta 42$, respectively (Figures 3c and $\mathrm{d}$ ). These validation experiments using EpiMap ELISA with well-characterized SAF-32, 6D11, 1E11 and 4G8 suggest its potential benefits in characterizing other specific binding interactions with PrPC or $\mathrm{A} \beta 42$.

\section{Protein epitope mapping with the EpiMap ELISA}

The synthetic $A \beta 40$ and $A \beta 42$ used in this experiment showed different results. The majority of $A \beta 40$ isoforms consisted of monomers; however, $A \beta 42$ isoforms consisted of monomers to tetramers in Tris-Tricine non-denaturing electrophoresis (Figure 4a). A $\beta 42$-binding epitopes in PrPC were elucidated using the PrPC EpiMap ELISA with recombinant $A \beta 42$ and 6E10 antibodies (Figure 4b). A previous study by Lauren et al. ${ }^{39}$ reported that residues $95-110$ of the PrPC sequence were necessary for $\mathrm{A} \beta 42$ binding. The $\mathrm{N}$-terminal region of PrPC was also suggested to be involved in mediating binding by another study ${ }^{40}$ Our PrPC EpiMap ELISA showed that epitopes 93-119 as well as 23-39 were involved in binding, as previously reported. Similarly, when synthetic A $\beta 40$ was applied, and the bound peptides were detected by the 6E10HRP antibody, the sum of normalized data from the PrPC EpiMap ELISA confirmed the involvement of the 93-113 and 123-166 epitopes. The N-terminal region showed weak binding that was not found to be significant (Figure 4d). The N-terminus-specific $6 \mathrm{E} 10 \mathrm{~A} \beta 42$ antibody was successfully used to detect bound $A \beta 42$; therefore, the C-terminal-specific antibody, 6D5, was also tested in a similar manner. When bound $\mathrm{A} \beta 42$ was detected by $6 \mathrm{D} 5$, significant interactions occurred at residues 23-40, 104-122 and 159-175 (Figure 4c).

The recombinant PrPC was applied to the A $\beta 42$ EpiMap ELISA to locate its A $\beta 42$ binding epitope. PrPC was detected by $\mathrm{T} 2$ or SAF-32 PrPC antibodies; however, no notable binding was detected (data not shown). Other combinations of PrPC antibodies, different blocking agents, buffers or trace amounts of copper ion did not improve PrPC binding in the A 342 EpiMap ELISA. All epitope mapping results are presented in Table 1.

\section{The recombinant PrPC and A $\beta 42$ interaction}

The bound PrPC against full-length A $\beta 42$ was detected. A $\beta 42-$ conjugated beads were incubated with $\mathrm{PrPC}$ and were detected by HRP-conjugated T2 antibody using luminescence (Figure 5). This test set (41040 \pm 1198 RLU) was significant compared to background where A $\beta 42$-conjugated (3896 \pm 585 RLU) and BA-conjugated (4582 \pm 458 RLU) beads were treated with HRP-conjugated anti-PrPC $(P<0.001)$. Although little non-specific binding with PrPC and BA was observed (15 309 $\pm 1666 \mathrm{RLU})$ in the negative control, PrPC and A $\beta 42$ binding was still found to be significant $(P<0.05)$ compared to the negative control. For the positive control, PrPCconjugated beads were incubated with HRP)-conjugated anti-PrPC (64 $804 \pm 533$ RLU).

\section{DISCUSSION}

Antibody epitopes and protein-protein interactions were identified by developing a 96-well-based epitope mapping a

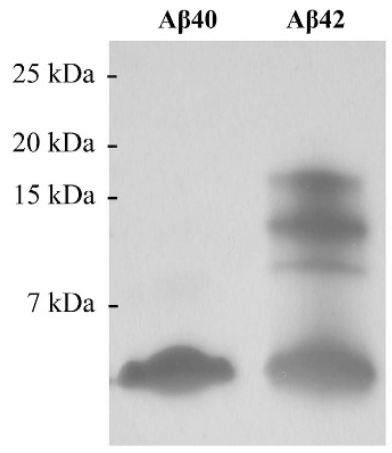

b

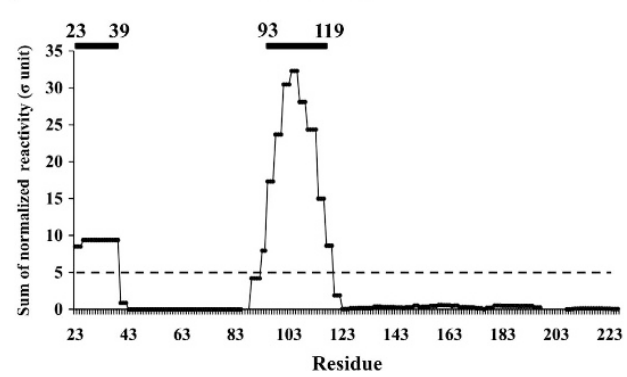

C
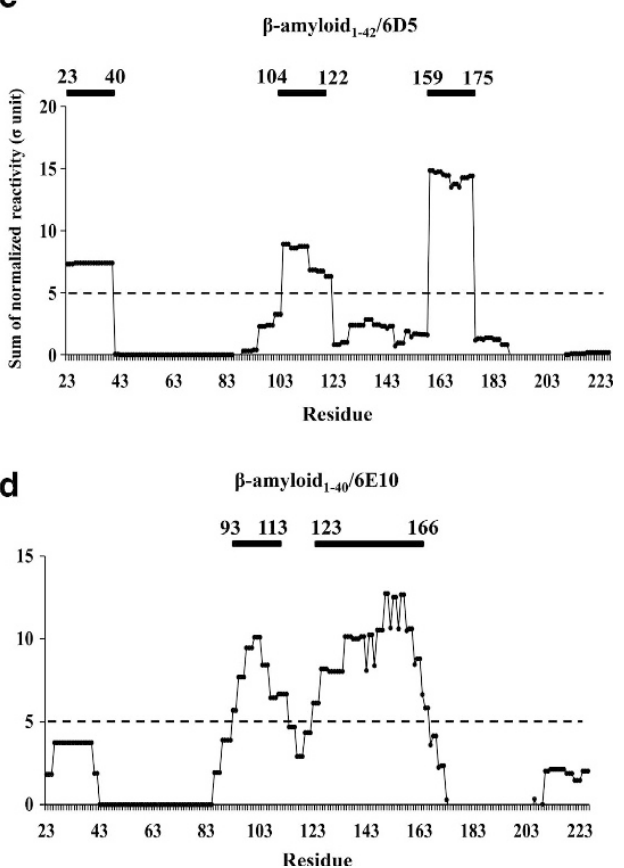

Figure 4 (a) Electrophoresis of $\beta$-amyloid ${ }_{1-40}(A \beta 40)$ and $\beta$-amyloid - $_{1-42}(A \beta 42)$. $A \beta 42$ was used in the cellular prion protein (PrPC) epitope mapping enzyme-linked immunosorbent assay (EpiMap ELISA) and detected by (b) the 6E10 antibody and (c) 6D5 Aß42 antibodies. (d) Monomeric A 440 bound to PrPC EpiMap ELISA was detected with the $6 \mathrm{E} 10$ antibody. The black bar and the number indicate the binding epitopes of $A \beta$ that were used in the PrPC EpiMap ELISA experiments. 
Table 1 Summary of epitope mapping results by the EpiMap ELISA

\begin{tabular}{|c|c|c|c|c|}
\hline $\begin{array}{l}\text { EpiMap } \\
\text { ELISA }\end{array}$ & $\begin{array}{l}\text { Protein/ } \\
\text { antibody }\end{array}$ & $\begin{array}{l}\text { Detection } \\
\text { antibody }\end{array}$ & $\begin{array}{l}\text { Reported } \\
\text { epitopes }\end{array}$ & $\begin{array}{l}\text { EpiMap } \\
\text { ELISA } \\
\text { results }\end{array}$ \\
\hline PrPC & SAF-32 & Anti-mouse IgG-HRP & $57-88$ & $\begin{array}{c}26-42 \\
86-103\end{array}$ \\
\hline PrPC & $6 \mathrm{D} 11$ & Anti-mouse IgG-HRP & $93-109$ & $89-116$ \\
\hline$A \beta 42$ & $1 \mathrm{E} 11$ & Anti-mouse IgG-HRP & $1-8$ & $1-15$ \\
\hline$A \beta 42$ & $\begin{array}{l}\text { 4G8- } \\
\text { HRP }\end{array}$ & - & $17-24$ & $13-29$ \\
\hline PrPC & $A \beta 42$ & 6E10-HRP & $\begin{array}{l}\text { N-terminus } \\
\text { 95-110 }\end{array}$ & $\begin{array}{c}23-39 \\
93-119\end{array}$ \\
\hline PrPC & $A \beta 42$ & $\begin{array}{l}\text { 6D5-Biotin/Avidin- } \\
\text { HRP }\end{array}$ & - & $\begin{array}{c}23-40 \\
104-122 \\
159-175\end{array}$ \\
\hline PrPC & $A \beta 40$ & 6E10-HRP & - & $\begin{array}{c}93-113 \\
123-166\end{array}$ \\
\hline$A \beta 42$ & PrPC & T2-HRP & - & - \\
\hline
\end{tabular}

Abbreviations: $A \beta 40, \beta$-amyloid ${ }_{1-40} ; A \beta 42, \beta$-amyloid ${ }_{1-42}$; EpiMap ELISA, epitope mapping enzyme-linked immunosorbent assay; HRP, horseradish peroxidase; IgG, immunoglobulin G; PrPC, cellular prion protein.

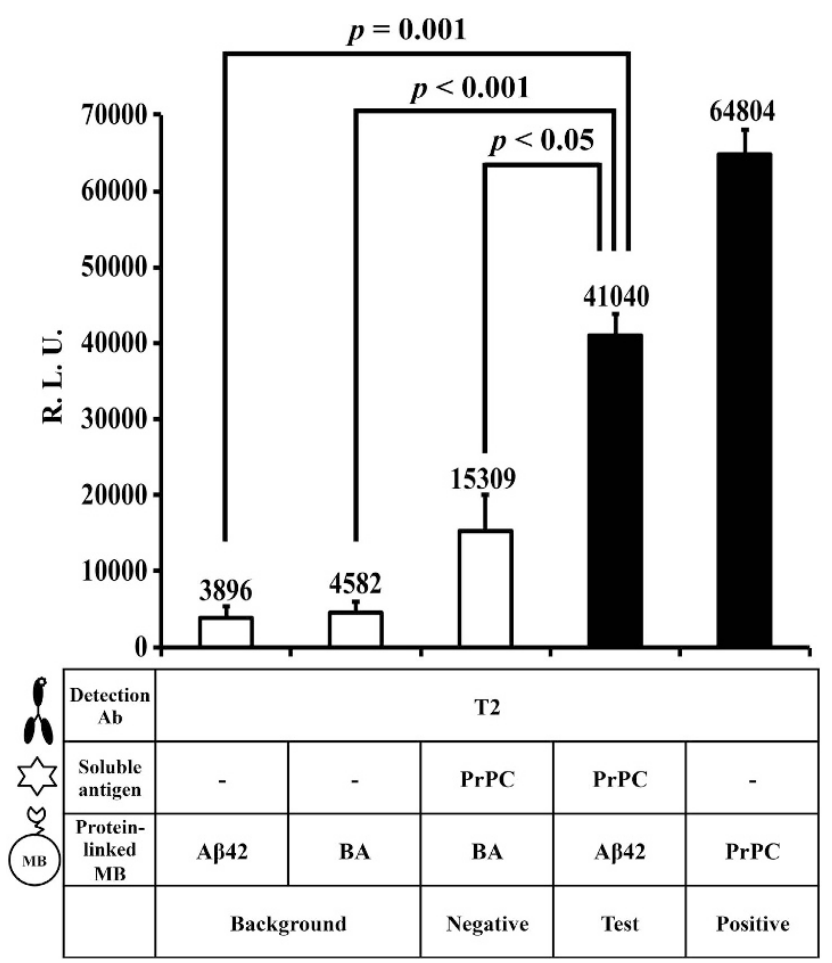

Figure 5 The precipitation of cellular prion protein ( $P r P C)$ by $\beta$-amyloid $_{1-42} \quad(A \beta 42)$-conjugated magnetic beads $(M B)$ were detected with the T2 antibody $(P<0.05)$. A $\beta 42-$ and BLOCK ACE (BA)-linked $M B$ were used in the negative controls, and PrPCcoupled MB was the positive control. Ab, antibodies.

ELISA using multiple overlapping peptides. The minimum length for an overlapping peptide is recommended to be at least an 8 mer for antibody epitope mapping (between 8 and 20 amino acids, generally); however, no reviews have been published regarding the minimum number of amino acids for peptide-protein interactions. Using shorter peptides with a slight rift between the overlapping peptides increases the resolution of epitope mapping; however, costs may be excessive if the protein is too long.

To avoid steric hindrance, the peptide design should include specific types of spacers at one of the ends. Generally, biotin attaches at the C-termini of peptides with a spacer moiety such as a polyethylene glycol or a GSGS motif. The use of avidin to link biotinylated peptides on the surface of the plate limits its application when biotinylated antibodies are the only viable option. To circumvent this problem, we used a cysteinemaleimide covalent bond to generate strong, irreversible binding for overlapping peptides. Activated-maleimides are attached on the surface through a $12 \AA$-long linker, followed by Pierce technical support. Therefore, the synthesis of overlapping peptides with spacers was not necessary because only cysteine was attached to one of the ends, except for peptides containing an inner cysteine in PrPC-overlapping peptides (amino acids 179, 214). Overlapping peptides generated from cysteine-containing proteins remove the inner cysteine or replace it with other amino acids for the following reasons: (1) two cysteines in an overlapping peptide may form an inner disulfide bond resulting in a circular peptide; and (2) free cysteines may be coupled to ligands, creating incorrect epitopes. Fundamentally, cysteine residues that are involved in forming the structure do not participate in the protein interaction. Therefore, cysteines in the protein must be substituted by other amino acids; consequently, in our experiments, an inner cysteine in the overlapping peptide was used to conjugate the peptide on a microplate. A review article published in 2004 described efficient and accurate epitope mapping strategies as well as detailed protocols. ${ }^{48}$

The EpiMap ELISA tests were performed rapidly and easily in the laboratory using basic manual or automated standard equipment for ELISA experiments. Peptide-conjugated microplates were prepared and preserved more easily compared to nitrocellulose membranes, which require specific techniques or machines to spot the peptides and were often fragile. Conjugating cysteinyl-overlapping peptides on the microplate was comparable to the same level of difficulty as coating antibodies or proteins for ELISA experiments. Increased hydrophobicity due to the incorporation of the cysteine at the end of the overlapping peptides was the only limitation to these experiments. Synthesis failure occurred in $\operatorname{PrPC}$ peptides no. $10,12,13,18,40$ and $A \beta 42$ peptide no. 15. Several hydrophobic peptides were dissolved in DMSO prior to conjugation to the maleimide-activated microtiter plate. Thus, when dissolving such peptides, the DMSO concentration was considered to be less than $1 \%(\sim 0.3 \%)$ in the final product.

Potentially, cysteinyl peptide dimers formed through their free sulfhydryl groups were reduced through dilution with phosphate buffer ( $\mathrm{pH} 4.5$ ) to protonate-free sulfhydryl groups with hydrogen. The $\mathrm{pH}$ after further dilution to $5 \mu \mathrm{g} \mathrm{ml}^{-1}$ in the dilution buffer was between 6.5 and 7.5 , allowing the 
efficient formation of thioether bonds between the maleimides and the free sulfhydryl groups. Not to mention the long preservation of lyophilized peptides requires the peptides to be maintained in a desiccated freezer to prevent moisture gain.

As Lauren et al. ${ }^{39}$ reported, the 6D11 PrPC antibody competed with the $\mathrm{A} \beta 42$-binding region. In addition, the PrPC EpiMap ELISA revealed that $A \beta 42$ also binds to the N-terminal PrPC (amino acids 23-39), which may be due to the high affinity of $\mathrm{A} \beta 42$ towards polybasic residues. ${ }^{40}$ Interestingly, the $6 \mathrm{E} 10$ antibody directed toward the N-terminus of $\mathrm{A} \beta 42$ detected bound $\mathrm{A} \beta 42$ in the PrPC EpiMap ELISA. The 6D5 antibody (specific to C-terminus of $\mathrm{A} \beta 42$ ) detected bound $\mathrm{A} \beta 42$ at both the $\mathrm{N}$ - and C-termini of the PrPC, which may be attributed to a number of causes; however, one possibility in this experiment may be the diverse conformational interaction between $\mathrm{A} \beta 42$ and PrPC. Nuclear magnetic resonance studies on $\mathrm{A} \beta 42$ suggested that residues 16-21 and 30-40 were located in the core of the fibrils, involving in amyloid assembly. ${ }^{51-53}$ Various $A \beta 42$ oligomeric structures may be as complex as the C-terminus toward the core or staggered $A \beta 42 \beta$-strands in fibrils. ${ }^{12}$ Furthermore, previous studies suggested that $A \beta 42$ oligomers along with the low molecular weight of $A \beta 42$ may result in its ability to bind to PrPC, implying that several types of $A \beta 42$ forms may interact with PrPC. ${ }^{39,54}$

A $\beta 40$ was also used in the PrPC EpiMap ELISA and was detected by $6 \mathrm{E} 10$. In relation to $\mathrm{A} \beta 40$, Pflanzner et al. ${ }^{55}$ suggested that monomeric $\mathrm{A} \beta 40$ was bound to $\mathrm{PrPC}$ at low concentrations. The monomeric form of $A \beta 40$ that we used bound to PrPC in a similar manner as $A \beta 42$. Similarities in the $3 \mathrm{D}$ structures of $\mathrm{A} \beta 40$ and $\mathrm{A} \beta 42$ are currently unknown and should be investigated in further studies. Overall, A $\beta 42$ interacted with PrPC independently from different epitopes. Depending on the epitope of the A $\beta 42$ antibody utilized, A $\beta 42$ binding to PrPC differed; therefore, their contact interfaces may be diverse or only a monomer from the $\mathrm{A} \beta 42$ multimer was involved in binding PrPC. ${ }^{42} \mathrm{~A} \beta 42$ and $\mathrm{A} \beta 40$ bound to PrPC; therefore, the $A \beta-\operatorname{PrPC}$ interaction may be diverse, suggesting that various structure types of $A \beta$ may be involved in binding.

When PrPC was used in the A $\beta 42$ EpiMap ELISA experiment, the bound PrPC was not detected with different PrPC antibodies against different epitopes (data not shown). The interaction between PrPC and A $\beta 42$ may be dependent on the $3 \mathrm{D}$ conformation of the $\mathrm{A} \beta 42$ oligomers. Therefore, the linear peptides used in the A $\beta 42$ EpiMap ELISA did not bind to PrPC. Recombinant PrPC and $\mathrm{A} \beta 42$ that were prepared in diverse oligomeric forms interacted efficiently in a bead-based ELISA, suggesting that possible interactions occur when the proteins are in their 3D structure. However, overlapping peptide no. 15 failed in the synthesis of the A $\beta 42$ EpiMap ELISA, which resulted in the absence of amino acid 42 . In protein interactions, one amino acid may be critical in determining the overall interaction, but no evidence was elucidated regarding whether this last amino acid has an important role in binding PrPC.

In conclusion, EpiMap ELISAs for PrPC and $\mathrm{A} \beta 42$ were developed to map the binding of epitopes with interactomes.
Residues 23-39 and 93-119 of the PrPC sequence were important in $\mathrm{A} \beta 42$ binding. These two regions interacted with A $\beta 42$ oligomers independently; however, their synergetic effect was not tested. In addition, 6E10 (against N-terminal A $\beta 42$ ) and 6D5 (against C-terminal A $\beta 42$ ) detected bound A $\beta 42$ on the PrPC EpiMap ELISA, suggesting that A $\beta 42$ interacted with $\mathrm{PrPC}$ in a diverse manner. The binding of the $\mathrm{A} \beta 40$ monomer with PrPC was reported in a previous publication, ${ }^{55}$ and similar $A \beta 40$ monomer binding sites were found, which suggests the possible role of $\mathrm{A} \beta 40$ conformations in the interaction with PrPC. Conversely, PrPC in the A $\beta 42$ EpiMap ELISA did not identify binding epitopes, which was thought to be caused by $3 \mathrm{D}$ conformation-dependent binding for $A \beta 40$ and $A \beta 42$.

Studies regarding PrPC binding to $\mathrm{A} \beta 42$ have utilized various methods that require genetic engineering or other laborious techniques. Our study identified protein interaction sites using the EpiMap ELISA, suggesting an easy platform that can be used to determine various binding sites of proteins within as little as $3 \mathrm{~h}$. Our identification of the interaction sites of $\operatorname{PrPC}$ with $\mathrm{A} \beta$ may be useful in therapeutic research for blockers or mimics against PrPC or A $\beta$. Recently, PrPC and $\mathrm{A} \beta$ interactions have shown to activate Fyn kinase in $\mathrm{AD} .^{56}$ Therefore, PrPC and $A \beta$ interactions are important for the understanding of toxic mechanisms of $A \beta$ oligomers, which should first be established to target these mechanisms in pharmaceutical interventions in $\mathrm{AD}$.

\section{CONFLICT OF INTEREST}

The authors declare no conflict of interest.

\section{ACKNOWLEDGEMENTS}

This study was funded by the Korea Centers for Disease Control \& Prevention, Ministry of Health \& Welfare (2011-E53001-00) and the National Research Foundation of Korea (2012R1A1A2A04).

1 Prusiner SB. Prions. Proc Natl Acad Sci USA 1998; 95: 13363-13383.

2 Ross CA, Poirier MA. Protein aggregation and neurodegenerative disease. Nat Med 2004; 10 (Suppl): S10-S17.

3 Prusiner SB, Hsiao KK. Human prion diseases. Ann Neurol 1994; 35 385-395.

4 Bueler H, Fischer M, Lang Y, Bluethmann H, Lipp HP, DeArmond SJ et al Normal development and behaviour of mice lacking the neuronal cellsurface PrP protein. Nature 1992; 356: 577-582.

5 Manson JC, Clarke AR, Hooper ML, Aitchison L, McConnell I, Hope J. 129/ Ola mice carrying a null mutation in PrP that abolishes mRNA production are developmentally normal. Mol Neurobiol 1994; 8: 121-127.

6 Turnbaugh JA, Westergard L, Unterberger U, Biasini E, Harris DA. The $\mathrm{N}$-terminal, polybasic region is critical for prion protein neuroprotective activity. PLoS One 2011; 6: e25675.

7 Bounhar Y, Zhang Y, Goodyer CG, LeBlanc A. Prion protein protects human neurons against Bax-mediated apoptosis. J Biol Chem 2001; 276: 39145-39149.

8 Roucou X, Giannopoulos PN, Zhang Y, Jodoin J, Goodyer CG, LeBlanc A Cellular prion protein inhibits proapoptotic Bax conformational change in human neurons and in breast carcinoma MCF-7 cells. Cell Death Differ 2005; 12: 783-795.

9 Brown DR, Schulz-Schaeffer WJ, Schmidt B, Kretzschmar HA. Prion protein-deficient cells show altered response to oxidative stress due to decreased SOD-1 activity. Exp Neurol 1997; 146: 104-112. 
10 Brown DR, Nicholas RS, Canevari L. Lack of prion protein expression results in a neuronal phenotype sensitive to stress. J Neurosci Res 2002; 67: 211-224.

$11 \mathrm{Kim}$ BH, Lee HG, Choi JK, Kim JI, Choi EK, Carp RI et al. The cellular prion protein (PrPC) prevents apoptotic neuronal cell death and mitochondrial dysfunction induced by serum deprivation. Brain Res Mol Brain Res 2004; 124: 40-50.

12 Ahmed M, Davis J, Aucoin D, Sato T, Ahuja S, Aimoto S et al. Structural conversion of neurotoxic amyloid-beta(1-42) oligomers to fibrils. Nat Struct Mol Biol 2010; 17: 561-567.

13 Christensen HM, Harris DA. Prion protein lacks robust cytoprotective activity in cultured cells. Mol Neurodegener 2008; 3: 11.

14 Selkoe DJ. Biochemistry and molecular biology of amyloid beta-protein and the mechanism of Alzheimer's disease. Handb Clin Neurol 2008; 89: 245-260.

15 Tam JH, Pasternak SH. Amyloid and Alzheimer's disease: inside and out. Can J Neurol Sci 2012; 39: 286-298.

16 Walsh DM, Selkoe DJ. Deciphering the molecular basis of memory failure in Alzheimer's disease. Neuron 2004; 44: 181-193.

17 Gouras GK, Tampellini D, Takahashi RH, Capetillo-Zarate E. Intraneuronal beta-amyloid accumulation and synapse pathology in Alzheimer's disease. Acta Neuropathol 2010; 119: 523-541.

18 Busciglio J, Pelsman A, Wong C, Pigino G, Yuan M, Mori $\mathrm{H}$ et al. Altered metabolism of the amyloid beta precursor protein is associated with mitochondrial dysfunction in Down's syndrome. Neuron 2002; 33: 677-688.

19 Cataldo AM, Petanceska S, Terio NB, Peterhoff CM, Durham R, Mercken M et al. Abeta localization in abnormal endosomes: association with earliest Abeta elevations in AD and Down syndrome. Neurobiol Aging 2004; 25: 1263-1272.

20 D'Andrea MR, Nagele RG, Wang HY, Peterson PA, Lee DH. Evidence that neurons accumulating amyloid can undergo lysis to form amyloid plaques in Alzheimer's disease. Histopathology 2001; 38: 120-134.

21 Echeverria V, Cuello AC. Intracellular A-beta amyloid, a sign for worse things to come? Mol Neurobiol 2002; 26: 299-316.

22 Gouras GK, Tsai J, Naslund J, Vincent B, Edgar M, Checler F et al. Intraneuronal Abeta42 accumulation in human brain. Am J Pathol 2000; 156: $15-20$

23 Ohyagi Y, Asahara H, Chui DH, Tsuruta Y, Sakae N, Miyoshi K et al. Intracellular Abeta42 activates p53 promoter: a pathway to neurodegeneration in Alzheimer's disease. FASEB J 2005; 19: 255-257.

24 De Strooper B. Proteases and proteolysis in Alzheimer disease: a multifactorial view on the disease process. Physiol Rev 2010; 90: 465-494.

25 Hardy JA, Higgins GA. Alzheimer's disease: the amyloid cascade hypothesis. Science 1992; 256: 184-185.

26 Hardy J, Selkoe DJ. The amyloid hypothesis of Alzheimer's disease: progress and problems on the road to therapeutics. Science 2002; 297: 353-356.

27 Lee HG, Zhu X, Castellani RJ, Nunomura A, Perry G, Smith MA. Amyloidbeta in Alzheimer disease: the null versus the alternate hypotheses J Pharmacol Exp Ther 2007; 321: 823-829.

28 Ashe KH, Zahs KR. Probing the biology of Alzheimer's disease in mice. Neuron 2010; 66: 631-645.

29 Caughey B, Lansbury PT. Protofibrils, pores, fibrils, and neurodegeneration: separating the responsible protein aggregates from the innocent bystanders. Annu Rev Neurosci 2003; 26: 267-298.

30 Haass C. Selkoe DJ. Soluble protein oligomers in neurodegeneration: lessons from the Alzheimer's amyloid beta-peptide. Nat Rev Mol Cell Biol 2007; 8: 101-112.

31 Klein WL, Krafft GA, Finch CE. Targeting small Abeta oligomers: the solution to an Alzheimer's disease conundrum? Trends Neurosci 2001; 24: 219-224.

32 Ferreira ST, Vieira MN, De Felice FG. Soluble protein oligomers as emerging toxins in Alzheimer's and other amyloid diseases. IUBMB life 2007; 59: 332-345.

33 Dong S, Duan Y, Hu Y, Zhao Z. Advances in the pathogenesis of Alzheimer's disease: a re-evaluation of amyloid cascade hypothesis. Trans/ Neurodegener 2012; 1: 18

34 Chakravarthy B, Menard M, Ito S, Gaudet C, Dal Pra I, Armato U et al. Hippocampal membrane-associated p75NTR levels are increased in Alzheimer's disease. J Alzheimers Dis 2012; 30: 675-684.

35 Shankar GM, Bloodgood BL, Townsend M, Walsh DM, Selkoe DJ, Sabatini BL. Natural oligomers of the Alzheimer amyloid-beta protein induce reversible synapse loss by modulating an NMDA-type glutamate receptor-dependent signaling pathway. J Neurosci 2007; 27: 2866-2875.
36 Magdesian MH, Carvalho MM, Mendes FA, Saraiva LM, Juliano MA, Juliano $\mathrm{L}$ et al. Amyloid-beta binds to the extracellular cysteine-rich domain of Frizzled and inhibits Wnt/beta-catenin signaling. J Biol Chem 2008; 283: 9359-9368.

37 De Felice FG, Vieira MN, Bomfim TR, Decker H, Velasco PT, Lambert MP et al. Protection of synapses against Alzheimer's-linked toxins: insulin signaling prevents the pathogenic binding of Abeta oligomers. Proc Natl Acad Sci USA 2009; 106: 1971-1976.

38 Benilova I, De Strooper B. Prion protein in Alzheimer's pathogenesis: a hot and controversial issue. EMBO Mol Med 2010; 2: 289-290.

39 Lauren J, Gimbel DA, Nygaard HB, Gilbert JW, Strittmatter SM. Cellular prion protein mediates impairment of synaptic plasticity by amyloid-beta oligomers. Nature 2009; 457: 1128-1132.

40 Chen S, Yadav SP, Surewicz WK. Interaction between human prion protein and amyloid-beta (Abeta) oligomers: role OF N-terminal residues. J Biol Chem 2010; 285: 26377-26383.

41 Kessels HW, Nguyen LN, Nabavi S, Malinow R. The prion protein as a receptor for amyloid-beta. Nature 2010; 466: E3-E4. (discussion E-5).

42 Gallion SL. Modeling amyloid-beta as homogeneous dodecamers and in complex with cellular prion protein. PLoS One 2012; 7: e49375.

43 Frank R. The SPOT-synthesis technique. Synthetic peptide arrays on membrane supports-principles and applications. J Immunol Methods 2002; 267: 13-26.

44 Geysen HM, Rodda SJ, Mason TJ, Tribbick G, Schoofs PG. Strategies for epitope analysis using peptide synthesis. J Immunol Methods 1987; 102: 259-274.

45 Rodda SJ, Tribbick G. Antibody-defined epitope mapping using the multipin method of peptide synthesis. Methods 1996; 9: 473-481.

46 Zahn R, von Schroetter C, Wuthrich K. Human prion proteins expressed in Escherichia coli and purified by high-affinity column refolding. FEBS Lett 1997: 417: 400-404.

47 Hayashi H, Takata M, Iwamaru Y, Ushiki Y, Kimura KM, Tagawa Y et al. Effect of tissue deterioration on postmortem BSE diagnosis by immunobiochemical detection of an abnormal isoform of prion protein. $J$ Vet Med Sci 2004; 66: 515-520.

48 Carter JM, Loomis-Price L. B cell epitope mapping using synthetic peptides. In Coligan JE (ed.). Current Protocols in Immunology 2004. (Chapter 9:Unit 9 4).

49 Feraudet C, Morel N, Simon S, Volland H, Frobert Y, Creminon C et al. Screening of 145 anti-PrP monoclonal antibodies for their capacity to inhibit PrPSc replication in infected cells. J Biol Chem 2005; 280: 11247-11258.

50 Spinner DS, Kascsak RB, Lafauci G, Meeker HC, Ye X, Flory MJ et al. CpG oligodeoxynucleotide-enhanced humoral immune response and production of antibodies to prion protein PrPSc in mice immunized with 139A scrapie-associated fibrils. J Leukoc Biol 2007; 81: 1374-1385.

51 Petkova AT, Ishii Y, Balbach JJ, Antzutkin ON, Leapman RD, Delaglio F et al. A structural model for Alzheimer's beta -amyloid fibrils based on experimental constraints from solid state NMR. Proc Natl Acad Sci USA 2002; 99: 16742-16747.

52 Torok M, Milton S, Kayed R, Wu P, McIntire T, Glabe CG et al. Structural and dynamic features of Alzheimer's Abeta peptide in amyloid fibrils studied by site-directed spin labeling. J Biol Chem 2002; 277: 40810-40815.

53 Sanchez de Groot N, Pallares I, Aviles FX, Vendrell J, Ventura S. Prediction of "hot spots" of aggregation in disease-linked polypeptides. BMC Struct Biol 2005; 5: 18.

54 Calella AM, Farinelli M, Nuvolone M, Mirante O, Moos R, Falsig J et al. Prion protein and Abeta-related synaptic toxicity impairment. EMBO Mol Med 2010; 2: 306-314.

55 Pflanzner T, Petsch B, Andre-Dohmen B, Muller-Schiffmann A, Tschickardt S, Weggen $\mathrm{S}$ et al. Cellular prion protein participates in amyloid-beta transcytosis across the blood-brain barrier. J Cereb Blood Flow Metab 2012; 32: 628-632.

56 Um JW, Strittmatter SM. Amyloid- $\beta$ induced signaling by cellular prion protein and Fyn kinase in Alzheimer disease. Prion 2013; 7: 37-41.

(c) (i) $(-)$ This work is licensed under a Creative Commons Attribution-NonCommercial-NoDerivs 3.0 Unported License. To view a copy of this license, visit http:// creativecommons.org/licenses/by-nc-nd/3.0/ 